\title{
Organizational Perceptions, Leadership and Performance in Work Settings: Do they Interrelate?
}

\section{Percepciones Organizacionales, Liderazgo y Desempeño en el Trabajo: ¿Están Relacionados?}

\author{
Aharon Tziner \\ Rudi Kaufmann* \\ Cristinel Vasiliu* \\ Netanya Academic College \\ University of Nicosia \\ Nuria Tordera \\ Bucharest Academy of Economics Studies \\ University of Valencia
}

\begin{abstract}
An in depth review of literature shows that there is a pressing need to holistically understand how and why the organizational leadership process affects organizational behavior in outcomes (e.g. job performance) differently, depending on various national culture settings. One approach may seek to unveil the moderation of cultural values on the relationship between preferred as well as exhibited styles of leadership and behavioral organizational outcomes. An alternative approach may explore how and why cultural values affect the relationship between the quality of leader - subordinate relationships (LMX) and behavioral organizational outcomes differently. Moreover, as we notice a constant growth of aged workers in the composition of the work force in the Western World, these approaches should be addressed in relation to older managers and workers. The present paper attempts to reconcile these diametrically opposed approaches by conceiving a theoretical model synthesizing organizational justice, organizational leadership styles, LMX and behavioral organizational outcomes (i.e., job performance, organizational citizenship) as moderated by organizational culture in different national values settings and in relation to older employees. By conceptualizing the interrelationships of the various concepts, the paper provides a coherent basis for further research in this field.
\end{abstract}

Keywords: justice, leadership, perceptions, performance, values.

\begin{abstract}
Resumen. Una revisión en profundidad de la literatura muestra que hay una importante necesidad de comprender de manera integral cómo y por qué, dependiendo de la cultura nacional, el proceso de liderazgo influye de manera diferente en los resultados del comportamiento organizacional (desempeño en el trabajo, por ejemplo). Una de las perspectivas trata de desvelar el efecto moderador de los valores culturales en la relación entre los estilos de liderazgo preferidos y exhibidos con los resultados del comportamiento organizacional. Un enfoque alternativo explora cómo y por qué los valores culturales influyen diferencialmente en la relación entre la calidad de las relaciones líder-subordinado (LMX) y los resultados del comportamiento organizacional. Además, en tanto se aprecia un crecimiento constante de los trabajadores mayores en la composición de la fuerza de trabajo en el mundo occidental, estos enfoques deben ser planteados en conexión con los empleados y directivos de más edad. El presente artículo intenta conciliar estos enfoques diametralmente opuestos para concebir un modelo teórico que sintetice las relaciones entre la justicia organizacional, los estilos de liderazgo organizacional, las relaciones líder-miembro y los resultados del comportamiento organizacional (p. ej., el desempeño del trabajo, la ciudadanía organizativa), moderados por la cultura organizacional en diferentes valores nacionales y en relación a los empleados mayores. Al conceptuar la interrelación de los diversos conceptos, el artículo proporciona una base coherente para más investigación en este campo.
\end{abstract}

Palabras clave: desempeño, justicia, liderazgo, percepciones, valores.

Value-based constructs such as work values and professional ethics, along with associated behaviours, have been ubiquitous engines of social change on a variety of levels. The effects of these constructs have been revealed in a wide range of studies, which range from history to moral philosophy and across the social sciences (Loftquist \& Dawis, 1978). The study of values is important to organizations because knowledge

\footnotetext{
* Both authors have equally contributed to this paper and their names are listed in an alphabetical order. Correspondence on this article should be sent to Aharon Tziner, Schools of Behavioral Studies and Business Administration, Netanya Academic College, Jerusalem, Israel. E-mail address:atziner@netanya.ac.il
}

of individual and group-level value structures can help managers understand and predict attitudes towards motivational processes, and other important organizational outcomes (Meglino \& Ravlin, 1998). Many types of connections between values and work-related behaviours have been documented (Rokeach, 1973; Dawis, 1991), and individual-level value constructs have played important roles in need-based theories of motivation such as the Self-Determination Theory (Deci \& Ryan, 2002). Also, value-based constructs are critical to theories of person-organization fit (Edwards, 2004) and in explaining general congruence patterns between employee values and attitudes. In addition, 
there are numerous studies that examine values from a cross-cultural perspective, both at the level of individual value structures (Schwartz \& Bilsky, 1990) and in the collective sense of shared values, such as in Hofstede's studies of value- based elements of national culture (Hoftstede, 2001; Hofstede \& Peterson, 2000). Another example is the Global Leadership and Organizational Behaviour Effectiveness (GLOBE) research program, which has identified different patterns of connections between shared value structures as revealed in national cultures and various leadership behaviors (House, Hanges, Javidan, \& Dorfman, 2004; Javidan, \& House, 2001). In a world that is increasingly interconnected across national, regional, and cultural boundaries, the understanding of value structures and how variability in value structures may affect organizational processes is gaining in importance.

\section{Individual values}

Values may be defined as personal beliefs in the relative desirability of different modes of conduct and end states of existence (Rokeach, 1973). In addition to understanding values as beliefs, values can be considered as transformations of a psychological need (Super, 1995). Thus, values may be defined in reference to categories of needs, and as such may be considered "second-order needs" (Loftquist \& Dawis, 1978). We feel that values are best defined as belief structures that are also connected to particular categories of needs (Elizur, 1984; Tziner \& Elizur, 1987). As such, values represent common elements in need dimensions, and they serve as reference dimensions for the description of needs. Through their connection to needs, values can produce states of psychological tension, which lead to cognition, affect, and behaviour. Also, particular values operate together as elements of individuals' value systems, which are collections of beliefs that together address the desirability of multiple modes of conduct and end states (Rokeach, 1973). Such value systems can be particularly effective at predicting important work-related behaviours (Maio \& Olson, 1998, Schwartz \& Bilsky, 1990).

As values are derived from needs (Super, 1995), psychological needs serve as antecedents for values. Because values, in turn, serve as a representation and transformation of needs, they are enduring, but because they address multiple modes of conduct or end states of existence, they are broader and more basic than interests are.

\section{Cultural Values}

National culture helps to determine which personal values should be pursued and what sort of gratification should be sought. They set normative standards to judge and select among alternative behaviours and courses of action (Latham \& Pinder, 2005). For example, effects of cultural values can be seen in the shaping of motives derived from concepts of the self, such as in the degree of challenge inherent in goal levels and the degree of approach or promotion focus versus avoidance tendencies in self-regulatory processes (Erez, 2008).

The term culture has numerous meanings and definitions. For example, culture has been defined as unstated standard operation procedures or ways of doing things (Triandis, 1994); as the collective programming of the mind and as the characteristic profile of a society with respect to its values, norms and institutions (Hofstede, 1980). Although there is no standard definition of culture, many emphasize that culture is shared, adaptive or has been adaptive at some point in the past, and transmitted across time and generations (Gelfand, Erez, \& Aycan, 2007; Triandis 1994).

Research using a variety of typologies has shown that national cultural values are related to organizational phenomena (e.g., Hofstede, 1980). Despite the fact that there are many cultural frameworks to choose from, Hofstede offers the most influential framework for differentiation of nations in relation to their cultural values. His work has guided cross-cultural research for over 20 years (e.g., Hofstede, 2001). It comprises five dimensions: power distance, individualism-collectivism, masculinity-femininity, uncertainty avoidance and long-term orientation. So far, only a small number of studies have addressed connections between personal-level values and leadership from a cross-cultural perspective.

\section{Leadership styles}

Leader-follower outcomes are a specific type of performance that has received extensive attention. Furthermore, within the leadership literature there are many studies that examine connections between traits and leadership behaviours (e.g., Walumbwa \& Schaubroeck, 2009). While there is no shortage of work that examines connections between leadership and traits, less work considers the relationships between individual-level values and leadership behaviours. In the same vein, when existing studies have examined connections between leadership behaviour and value structures, these connections have frequently been examined from the perspective of shared values (e.g., Brown \& Trevino, 2009). With exception of several recent studies, there seems to be a need in the leadership literature to address the influence of personal values on leadership styles of managers.

Theories of leadership inhabit a large conceptual range and include theories focused on individual differences, situational characteristics, and combinations of both individual differences and situational elements. 
In recent years, the balance of development in leadership theory has focused on a broad range of behaviours, to include both transactional and transformational leadership behaviours, as well as instrumental and laissez faire leadership behaviours.

Also, there is an increasing amount of research that suggests that both transactional and transformational leadership behaviours are related to effective leadership. Transactional leadership behaviours, which focus on clarifying employee role and task requirements, providing performance-based reinforcement, and assisting employee self-regulation (Thorbjornsen and Supphellen, 2011) through goal setting and feedback seeking behaviours often result in successful leadership. However, transformational leadership behaviours, which primarily focus on creating developmental changes in followers' values, employees' and other stakeholders' identity (Balmer, 2011), and psychological needs, can offer a contribution above and beyond transactional leadership behaviour. It is likely that this effect occurs through an emphasis on intrinsic motivation, which serves to augment the extrinsic elements within transactional leadership approaches. An alternative theoretical approach to understanding the leadership process, the LMX theory, is discussed in the next paragraph.

\section{LMX}

One of the theories seeking to explain the dynamics of this process is leader-member exchange (LMX), which holds that managers do not exhibit the same leadership styles (e.g., transactional, transformational) to all subordinates, but rather develop different types of exchange relationships with different employees. These may range from high-quality exchanges based on trust and liking, to low quality relations based on formal job requirements and the employment contract. Employees who enjoy high-quality LMX with their superiors typically receive more opportunities, emotional support, and cooperative interactions than those in low quality LMX relationships (Liden \& Graen, 1980). Thus, it has been shown to be related to several correlates at the individual and group level (Tordera, González-Romá \& Peiró, 2008).

As LMX is premised on the notions of social exchange and reciprocity (Adams, 1965), subordinates offered high quality LMX are expected to feel compelled to reciprocate the preferential treatment they receive from their manager or supervisor. The positive affect, respect, loyalty, and perceived obligation characteristics of high-quality LMX should motivate better job performance, organizational citizenship and extrarole behaviour (Morhart et al., 2009) such as working overtime and offering extra help to co-workers and supervisors. Empirical support for this prediction was provided by the meta-analysis of Gerstner and Day
(1997), who reported a correlation of .31 between LMX and supervisory performance ratings. More recent studies have found further evidence of this link (Kacmar et al., 2003; Wang et al., 2005).

However, other factors related to the organizational culture, or leadership processes have been neglected. In as much as high-quality LMX is likely to affect employees' performance and values, fundamental elements in maintaining an organization's viability and competitive advantage, it is important to identify factors that are conducive to such interpersonal relations in the workplace. Recent research suggests that perceived fairness of leaders may be one such factor (Wayne et al., 2002). The use of the term "fairness" in this context appears in organizational justice literature (Bell, Wiechmann \& Ryan, 2006) and originated in the field of social interactions (Greenberg, 1990).

\section{Organizational Justice}

Justice-related consequences include some of the most important outcomes studied by management researchers. For example, perceptions of unfair or unjust treatment have been associated with many harmful effects including negative health outcomes, intentional deviant behaviours, and withdrawal behaviours (Pinder, 2008). To explain the power of justicerelated phenomena, we must recognize that employees in organizations constantly tend to examine the actions taking place within the organization, in an attempt to determine whether the action was fair, or in other words, whether justice exists within the organization. To this end, they explore according to three types of criteria:

- The first criterion relates to practical implications, i.e. personal gain or loss, which derive from the employee's feeling that the decisions reached were just and right. This fairness is examined in the Distributive Justice Theory (Adams, 1965).

- The second relates to the way in which the decision to take action was made: the employee assesses whether the processes that led to the decision were fair (Thibaut, Friedland \& Walker, 1974).

- The third relates to the approach adopted during planning and application (Sheppard, Lewicki \& Minton, 1992), i.e. the treatment employees receive during implementation, their feeling that the organization imparted new information and treated them sensitively and fairly. This fairness is examined in the Interactional Justice Theory (Tyler \& Bies, 1990).

As research has shown that justice perceptions influence a variety of outcomes (Cohen-Charash \& Spector 2001), it seems reasonable to assume that when employees perceive their supervisors to be treating them fairly, they are likely to develop high-quality 
exchange relationships. Yet, this dynamic may not be as straightforward as it might appear. LMX theory has also been criticized for paying little attention to possible moderators of the relationship between LMX and job performance. Furthermore, it has been suggested that the relationship between perceived organizational justice and LMX may be moderated by organizational culture. For example, low perceived organizational justice might not lead to low-quality LMX if employees believe the inequity to be attributable to an organizational culture that does not reward workers or praise them for good performance, rather than to deliberate unfair behaviour of their managers. If the dominant organizational culture is perceived to perpetuate a reality of injustice, the employees may be more prone to excuse and be tolerant of inequity on the part of their superiors.

The LMX theory is suggested to be applied to a specific group of workers, which is anticipated to gain significant importance in the future, the 'greying workforce'. Some idiosyncratic aspects regarding this group are provided in the next paragraph.

\section{The 'greying workforce'}

By focusing on older workers and their involvement in the work role, the present paper attempts to address one of the more challenging phenomena in the understanding of the workforce of the near future, what has been called the 'greying' of the workforce.

Since the early 1970s, there has been a constant decline in labor force participation and in employment rate of workers older than 55 years (Von Nordheim, 2003). Half a century ago, the average exit age in the European Union was above 65 years; recent rates show it to be around 59.9 (data from 2001; after Von Nordheim, 2003). The European Commission has paid attention to the progressive shrinking of the workforce, which will occur by 2015 , if certain strategies to retain older workers in their workplaces are not taken into consideration. It has been estimated that the number of people in the 20-29 age group will fall by $20 \%$, whereas the number in the 50-64 age group will increase by $25 \%$. However, the latter group is the one that is the least represented in nowadays labor market, especially due to early retirement practices (Von Nordheim, 2003).

It has to be pointed out that early retirement has different consequences, which will have important effects for societies and companies in the short and, most importantly, in the long term. These consequences might be considered at three levels. First of all, early retirement directly affects the financing of the social security system. For instance, due to early retirement the number of beneficiaries of retirement benefits will increase, whereas the number of employees paying into the security system will decrease (Forteza \& Prieto, 1994). Furthermore, early retirement also affects organizations in the form of brain drain and loss of skilled employees (Talaga \& Beehr, 1989). Finally, decisions to take early retirement influence older workers themselves, for instance in terms of their finances, health, or life satisfaction.

Due to the increasing tendency of greying workforce, most European countries are studying different strategies to keep older employees in the labour market (Von Nordheim, 2003). In some sectors (e.g. nursing), we can already observe a lack of labor force. In other sectors, older employees represent valuable human capital, and therefore the organizations have to develop policies and practices oriented towards their retention. This is the case with regard to the situation of older workers in management positions. For this reason, to include a sample of managers in future research projects differentiating as to their specific value set, will offer added knowledge to the subject. Research on early retirement practices has mainly been centered in the individual factors that are related to workers' decisions to retire early. However, decisions of older workers to exit or remain in their work roles do not evolve in a social vacuum. Research that considers the role of social and organizational influences in older workers' involvement with their work role is needed. Organizational factors such as leadership and organizational culture have been emphasized as playing an important role in the retention of older workers (Beehr et al., 2006; Hedge, Borman \& Lammlein, 2006; Henkens, 1999; Rosen \& Jerdee, 1977). However, there is a lack of research addressing those issues.

Moreover, embracing an intercultural dimension will allow future researches to analyze possible differences in the way that different organizational factors are faced with regard to older workers in different geographic areas. Thus, the consideration of managers operating in different European (and non-European countries) will also increase the value of further research.

In this sense, the present paper calls to pay heightened attention to the conditions and factors that motivate older employees to stay in the labour market. This approach, together with the development of organizational cultures and practices that take into account the special needs of older workers, is opening the way towards the examination of factors that may promote a "delayed exit culture".

\section{Organizational culture}

Organizational culture influences behaviour in organizations (Bonavia, 2006; Bonavia, Molina \& Boada, 2009), and may be suggested as a potential moderator. Indeed a proximal concept to culture, organizational climate, has been found to moderate the 
relationship between LMX and individual level results such as perceptions of role overload and well-being (Tordera, González-Romá \& Peiró, 2008). However, the relationship between organizational culture and leadership has received little attention in the literature. Some studies have shown that specific leadership behaviours are associated with distinct organizationalcultural characteristics. Moreover, organizational culture might be a contextual factor leading to the emergence of a specific leadership style. Schein (1992) claims that organizational culture controls the manager more than the manager controls the culture, through the automatic filters that bias the manager's perceptions, thoughts and feelings. Therefore, although LMX is based on the dyadic employee-manager interaction, it also is likely to be affected by organizational-cultural dimensions.

Organizational culture is viewed in the literature as a multifaceted abstraction with several dimensions, which have varying degrees and directions of effect on both employees' behaviour (e.g., Sheridan, 1992) and organizational performance (e.g., Denison, 1984, 1990). In this study, we used O'Reilly III, Chatman and Caldwell's (1991) classification of organizational culture.

Summarizing, in our model, we posit the following relationships between individual values, national cultural values, leadership styles, LMX, organizational justice, organizational culture, and performance. We have reached the point where we can sum up the entire exposition of this paper with a holistic conceptualization (Figure 1) so far not provided by literature. The model hypothesizes employees' needs and values (determined by cultural values and age), leadership styles, perceived organizational justice and LMX as the antecedent variables and job performance (such as compliant, deviant, organizational citizenship, and in-role and extra-role behaviour) as the outcome variable. The relationship between leadership styles, organizational justice, LMX and job performance is suggested to be moderated by organizational culture.

\section{Recommended future research directions}

In view of these suggestions, a research program should be designed and conducted to examine the moderating role of organizational culture on the links between organizational justice, leadership style (e.g., transformational vs. transactional), LMX, and job performance in various national cultural contexts. The countries to be chosen should provide for a consolidated view on countries (e.g., European countries) and to possibly differentiate as to 'established' and transition countries. Moreover, a future research project should target understanding how perceptions of organizational justice, leadership and organizational culture contribute to the performance of older managers in organizational and work settings. These issues are especially important with regard to management positions in organizations. The cumulated body of knowledge shows that cultural value differences preclude automatic transfer of findings from one culture to another. Therefore, it is essential to explore how organizational fairness, justice, leadership behaviours and organizational culture link to job performance and organizational citizenship in different national cultural contexts, triangulating quantitative and qualitative methods. On the practical ground, such knowledge will enhance functioning of international companies establishing in culturally different economic spaces.

\section{References}

Adams, J. S. (1965). Inequity in social exchange. In L. Berkowitz (Ed.), Advances in Experimental Social Psychology. Vol.2, (pp. 267-299). New York: Academic Press.

Balmer, J. M. T. (2011). Corporate Marketing Myopia and the Inexorable Rise of a Corporate Marketing Logic. European Journal of Marketing, 45, 1329- 1352.

Beehr, T. A., Glaser, K. M., Beehr, M. J., Beehr, D. E., Wallwey, D. A., Erofeev, D., \& Canali, K. G. (2006). The

Figure 1. The conceptualization guiding the paper's argumentation and reasoning

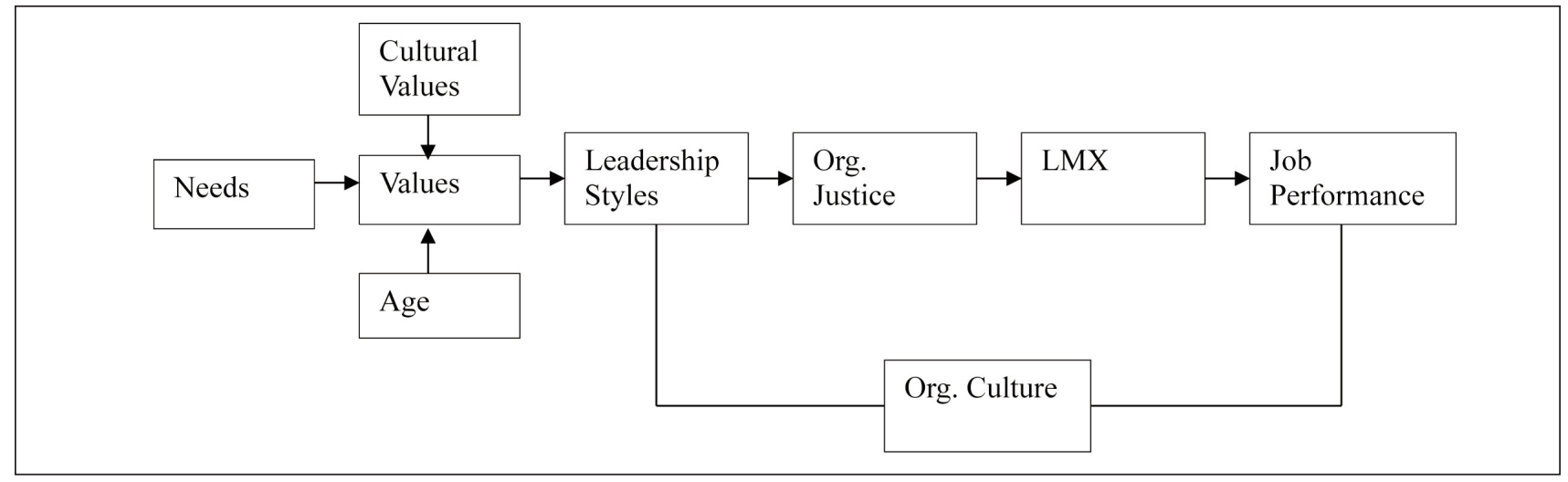


nature of satisfaction with subordinates: Its predictors and importance to supervisors. Journal of Applied Social Psychology, 36, 1523-1547.

Bell, B. S., Wiechmann, D., \& Ryan, A. M. (2006). Consequences of organizational justice expectations in a selection system. Journal of Applied Psychology, 91, 455466.

Bonavia, T. (2006). Preliminary organizational culture scale focused on artifacts. Psychological Reports, 99, 671-674.

Bonavia, T., Molina, G., \& Boada, J. (2009). Further examination of the organizational culture scale of artifacts. Psychological Reports, 105, 827-834.

Brown, M. E. \& Trevino, L. K. (2009). Leader-follower values congruence: Are socialized charismatic leaders better able to achieve it? Journal of Applied Psychology, 94, 478-490

Cohen-Charash, Y. \& Spector, P. E. (2001). The role of justice in organizations: A meta-analysis. Organizational Behavior and Human Decision Processes, 86, 278-321.

Dawis, R. V. (1991). Vocational interests, values, and preferences. In M. D. Dunnette \& L. M. Hough (Eds.), Handbook of industrial and organizational psychology, Vol. 2, $2^{\text {nd }}$ ed. (pp. 833-871). Palo Alto, CA: Consulting Psychologists Press.

Deci, E. L. \& Ryan, R. M. (2002). Self-determination research: Reflections and future directions. In E. L. Deci, \& R. M. Richard (Eds.), Handbook of Self-determination Research (pp. 431-441). Rochester, New York: University of Rochester Press.

Denison, D. R. (1984). Bringing corporate culture to the bottom line. Organizational Dynamics, 13, 5-22.

Denison, D. R. (1990). Corporate Culture and Organizational Effectiveness. New York: Wiley.

Dorn, D. \& Sousa-Poza, A. (2005). The determinants of early retirement in Switzerland. Swiss Journal of Economics and Statistics, 141, 247-283.

Edwards, J. R. (2004). Complementary and supplementary fit: A theoretical and empirical integration. Journal of Applied Psychology, 89, 822-34.

Elizur, D. (1984). Facets of work values: A structural analysis of work outcomes. Journal of Applied Psychology, 69, 379-389.

Erez, M. (2008). Social-cultural influences on work motivation. In R. Kanfer, G. Chen, \& R. D. Pritchard (Eds.), Work motivation: Past, present, and future (pp. 501-538). New York: Routledge/Taylor \& Francis Group.

Forteza, J. A. \& Prieto, J. M. (1994). Aging and work behavior. In H. C. Triandis, M. D. Dunette, \& L. M. Hough (Eds.), Handbook of Industrial and Organizational Psychology, $2^{\text {nd }}$ ed. (Vol. 4, pp. 447-483). Palo Alto, CA: Consulting Psychologists Press, Inc.

Gerstner, C. R. \& Day, D. V. (1997). Meta-analytic review of leader-member exchange theory: Correlates and construct issues, Journal of Applied Psychology, 82, 827-844.

Hedge, J. W., Borman, W. C., \& Lammlein, S. E. (2006). The aging workforce: Realities, myths, and implications for organizations. Washington, DC: American Psychological Association.
Henkens, K. (1999). Retirement intentions and spousal support: A multi-actor approach. Journal of Gerontology: Social Sciences, 54B, 63-73.

Hofstede, G. H. (1980). Culture Consequences: International Differences in Work-related Values. London, United Kingdom: Sage.

Hofstede, G. (2001). Culture's consequences: Comparing values, behaviors, institutions, and organizations across nations, $2^{\text {nd }}$ Ed. Thousand Oaks, CA: Sage.

Hofstede, G., \& Peterson, M. F. (2000). National values and organizational practices. In N. M. Ashkanasy, C. M. Wilderom, \& M. F. Peterson (Eds.), Handbook of organizational culture.and climate (pp. 401-414). Thousand Oaks, CA: Sage.

House, R. J., Hanges P. J., Javidan, M., \& Dorfman, P. W. (2004). Leadership, culture, and organizations: The GLOBE study of 62 societies. Thousand Oaks, CA: Sage.

Javidan, M., \& House, R. P. (2001). Cultural acumen for the global manager: Lessons from project GLOBE. Organizational Dynamics, 29, 289-305.

Kacmar, K. M., Witt, L. A., Zivnuska, S., \& Gully, S. M. (2003). The interactive effect of leader-member exchange and communication frequency on performance ratings. Journal of Applied Psychology, 88, 764-772.

Latham, G. P. \& Pinder, C. C. (2005). Work motivation: Theory and research at the down of the $21^{\text {st }}$ century. Annual Review of Psychology, 56, 485-517.

Loftquist, L. H. \& Davis, R. V. (1978). Values as secondorder needs in the theory of work adjustment, Journal of Vocational Behavior, 1, 12-19.

Maio, G. R. \& Olson, J. M. (1998). Values as truisms: Evidence and implications, Journal of Personality and Social Psychology, 74, 294-311.

Meglino, B. M. \& Ravlin, E. C. (1998). Individual values in organizations: Concepts, controversies, and research. Journal of Management, 24, 251-289.

Morhart, F. M., Herzog, W., \& Tomczak, T. (2009). Brandspecific leadership: turning employees into brand champions. Journal of Marketing, 73, 122-142.

O'Reilly III, C. A., Chatman, J., \& Caldwell, D. F. (1991). People and organizational culture: A profile comparison approach to assessing person-organization fit. Academy of Management Journal, 34, 487-516.

Pinder, C. C. (2008). Work motivation in organizational behavior (2nd ed.). New York, NY US: Psychology Press.

Rokeach, M. (1973). The Nature of Human Values. New York: Free Press.

Rosen, B. \& Jerdee, T. H. (1977). Too old or not too old? Harvard Business Review, 55, 97-106.

Schein, E. H. (1992). Organizational Culture and Leadership. San Francisco, CA: Jossey-Bass.

Sheppard, B. H., Lewicki, R. J., \& Minton, J. W. (1992). Organizational justice: The search for fairness in the workplace. New York: Lexington Books/Macmillan.

Sheridan, J. E. (1992). Organizational culture and employee retention. Academy of Management, 35, 1036-1056.

Schwartz, S. H. \& Bilsky, W. (1990). Toward a theory of the universal content and structure of values: Extensions and 
cross-cultural replications. Journal of Personality and Social Psychology, 58, 878-91.

Super, D. E. (1995). Values: Their nature, assessment, and practical use. In D. E. Super, B. Super, \& Sverko (Eds.), Life roles, values, and careers: International findings of the Work Importance Study (pp. 54-61). San Francisco, CA: Jossey-Bass.

Talaga, J. A., \& Beehr, T. A. (1989). Retirement: A psychological perspective. In C. L. Copper \& I. T. Robertson (Eds.), International review of industrial and organizational psychology (pp. 185-211). Chichester, United Kingdom: Wiley.

Thibaut, J., Friedland, N. \& Walker, L. (1974). Compliance with rules: Some social determinants. Journal of Personality and Social Psychology, 30, 792-801.

Thorbjornsen, H. \& Supphellen, M. (2011). Determinants of core value behaviour in service brands. Journal of Services Marketing, 25, 68-76.

Tordera, N., González-Romá, V., \& Peiró, J. M. (2008). The moderator effect of psychological climate on the relationship between leader-member exchange (LMX) quality and role overload .European Journal of Work and Organizational Psychology , 17, 55-72.

Triandis, H. C. (1994). Culture and social behavior. New York: McGraw-Hill.

Tyler, T. R. \& Bies, R.J. (1990). Beyond formal procedures: The interpersonal context of procedural justice. In J.S.
Carroll (Ed.). Applied social psychology and organizational settings (pp. 77-98). Hillsdale, New Jersey: Lawrence Erlbaum Associates.

Tziner A. \& Elizur, D. (1987). Work values as "reinforcer groups." Is the underlying structure method free? Quality \& Quantity, 21, 377-392.

Von Nordheim, F. (2003). EU Policies in support of member state efforts to retain, reinforce and re-integrate older workers in employment. In H. Buck \& B. Dworschak (Eds.), Ageing and Work in Europe. Strategies at Company Level and Public Policies in Selected European Countries, (pp. 9-26) Demography and Employment. Stuttgart, Germany: IRB Verlag.

Walumbwa, F. O. \& Scaubroeck, J. (2009). Leader personality traits and employee voice behaviour: Mediating roles of ethical leadership and work group psychological safety. Journal of Applied Psychology, 94, 1275-1286.

Wang, H., Law, K. S., Hackett, R. D., Wang, D., \& Chen, Z. X. (2005). Leader-member exchange as a mediator of the relationship between transformational leadership and followers' performance and organizational citizenship behavior. Academy of Management Journal, 48. 420-432.

Wayne, S. J., Shore, L. M., Bommer, W. H., \& Tetrick, L. E. (2002). The role of fair treatment and rewards in perceptions of organizational support and leader-member exchange. Journal of Applied Psychology, 87, 590-598.

Manuscript Received: 29/05/2011

Revision Received: 26/10/2011

Accepted: 30/10/2011 